\title{
Interlocking Directorates and Political Cohesion among Corporate Elites ${ }^{1}$
}

\author{
Val Burris \\ University of Oregon
}

This study uses data on campaign contributions and methods of network analysis to investigate the significance of interlocking directorates for political cohesion among corporate elites. Using quadratic assignment procedure (QAP) regression, the author shows that social ties formed through common membership on corporate boards contribute more to similarity of political behavior than commonalities of economic interests, such as those associated with operating in the same industry or the same geographic region. Moreover, the politically cohesive effects of directorship ties remain robust even as one moves several links down the chain of indirect ties that connect top corporate officers to one another. The study thus provides empirical support for the thesis that social networks among corporate elites facilitate political cohesion within the business community.

Interlocking directorates among major U.S. corporations have been a focus of political and scholarly interest since the early 20th century. In recent decades, advances in computer technology and methods of network analysis have led to a virtual explosion of empirical studies of interlocking corporate directorates. Despite this extensive body of research, important questions remain as to the meaning and significance of director interlocks. As Mizruchi (1996) notes in his review of the literature, the question What do interlocks do? is perhaps the most crucial question confronting interlocks research. Critics of the early studies of director interlocks argued that this research was mostly descriptive and that the social, political, and economic effects of interlocking directorates were more often assumed than empirically demonstrated. Partly in response to this criticism, con-

\footnotetext{
${ }^{1}$ I wish to thank Bill Domhoff, Ken Hudson, Beth Mintz, Robert O'Brien, Caleb Southworth, and the AJS reviewers for their helpful comments on an earlier draft of this article. Direct correspondence to Val Burris, Department of Sociology, University of Oregon, Eugene, Oregon 97403. E-mail: vburris@uoregon.edu
}

(C) 2005 by The University of Chicago. All rights reserved.

0002-9602/2005/11101-0006\$10.00 
temporary scholars have sought to provide more direct evidence of the consequences that director interlocks have for the functioning of large corporations and the behavior of corporate elites.

One consequence that is often imputed to director interlocks is the potential to facilitate political cohesion among corporations and corporate elites. ${ }^{2}$ Disagreement over whether or not interlocking directorates serve this function is linked to a larger debate over how best to understand patterns of political consensus and cleavage within the business community (Mizruchi 1992, pp. 1-32). One view (generally associated with pluralist theory) argues that political consensus, when it occurs, is the contingent outcome of a coincidence of firm-specific or industry-specific interests-interests that are just as likely to divide corporations and corporate elites as they are to produce political unity. A second view (generally associated with elite theory or class cohesion theory) argues that potential divisions rooted in the parochial interests of individual firms or industries are reconciled or overridden by mechanisms of consensus formation that are embedded in social networks, such as those formed through interlocking directorates.

Most researchers now working in this area recognize that one can point to signs of both consensus and cleavage within the business community, and would reject the notion that one must choose between one-sided versions of either of these theories. Rather than debating whether business is essentially divided or essentially unified, the focus of research has turned to questions of specifying more precisely the forces that threaten to divide the business community at any given time, and the mechanisms by and conditions under which (some degree of) business unity is achieved. Whether or not interlocking directorates facilitate political cohesion within the business community is a key issue within this research agenda, and one that only recently has become subject to rigorous empirical study.

By far the most systematic effort to bring empirical evidence to bear on this question is Mizruchi's (1992) important study of interfirm relations and their impact on corporate political action. Mizruchi's findings are mixed but generally support the thesis that director interlocks increase the potential for political cohesion among corporations. Using testimony before Congress as a measure of corporate political action, Mizruchi shows that firms that are connected through interlocking directorates are more likely to express agreement on legislative matters, controlling for other

\footnotetext{
${ }^{2}$ Unless explicitly stated otherwise, I use "cohesion" in the objective rather than subjective sense of the term. That is to say, "cohesion" refers to the density of observable relations or similarity of observable behavior among actors, without any presumptions regarding the extent to which these are associated with subjective sentiments of solidarity or collective identity (cf. Mizruchi 1992, pp. 34-43).
} 
factors that could be expected to promote consensus. This is true both for "direct" interlocks (firms that are directly linked through a common director) and for "indirect" interlocks (firms that each have a director on the board of a third, intermediary firm). However, when political unity is measured in terms of corporate contributions to political candidates, the findings are ambiguous and slightly puzzling. Mizruchi reports that indirect interlocks between firms contribute significantly to similarity of political contributions (net of other factors), but that direct interlocks do not. Mizruchi interprets this seemingly anomalous finding as an indication that "structurally equivalent" positions within networks of interlocking directors may be more conducive to political cohesion than direct ties between firms. ${ }^{3}$ Whatever the merits of this hypothesis, the fact that direct interlocks do not contribute to similarity of campaign contributions is certainly contrary to the usual understanding of how director interlocks are thought to facilitate political cohesion.

Mizruchi's findings appear less puzzling when it is recognized that his measure of indirect interlocks is limited to one specific type of indirect interlock: the common membership by directors of industrial firms on the boards of leading financial corporations. Research has shown that the boards of large commercial banks and insurance companies provide important meeting grounds for some of the most influential and politically active members of the business community (Zeitlin 1974, 1976; Useem 1984; Mintz and Schwartz 1985; Bearden and Mintz 1987; Soref and Zeitlin 1987; Burris 1992). Hence, it is not surprising that joint participation within these exclusive "inner circles" might have consequences for political cohesion that other corporate interlocks do not. Mizruchi does not present evidence on whether indirect interlocks in general are significantly associated with similarity of political behavior.

It is important that Mizruchi's research be followed up with similar studies using data from other elections and other samples of firms. In this study, however, I wish to advance a different line of analysis-one that complements, rather than replicates, Mizruchi's research on the relationship between director interlocks and political cohesion. One of the early and most important findings of the research on interlocking directorates is the fact that "broken ties" (situations in which an interlock between firms is severed by the death or retirement of a director) are not typically restored through the exchange of a new director (Koenig, Gogel, and Sonquist 1979; Ornstein 1980; Palmer 1983). This finding has led many to the conclusion that the significance of director interlocks for firms

\footnotetext{
${ }^{3}$ In the language of social network analysis, "structurally equivalent" actors are ones who share a common pattern of ties to the larger network, even though they may not be directly tied to one another.
} 
cannot, in most cases, be located at the level of the specific interfirm dyad, but must be interpreted as a general resource that facilitates (through any of a number of equivalent channels) the flow of communication, monitoring of events, or projection of influence across the larger corporate network (Useem 1984; Mintz and Schwartz 1985; Stearns and Mizruchi 1986).

Research on interlocking directorates has been greatly enriched by studies that shift the focus of attention from dyads of interconnected firms to the structural position of firms within the overall interlock network. It is worth recalling, however, that the theoretical conclusions drawn by the authors of the original broken-tie studies pointed toward an even more radical reorientation of research on interlocking directorates. For Koenig et al. (1979), Ornstein (1980), and Palmer (1983), the fact that accidentally broken ties were not typically reconstituted with new ties to the same firm was taken as evidence that interlocks were not primarily interorganizational phenomena and might be better conceptualized as intraclass phenomena-that is, as social ties among corporate elites and other members of the capitalist class. ${ }^{4}$ This implied that the answer to the question What do interlocks do? ought to be pursued by studying the behavioral implications for corporate directors of their ties to other directors through common board memberships, rather than focusing exclusively on the behavioral implications for firms of their links to other firms through shared directors.

The thesis that interlocking directorates facilitate political cohesion among corporate elites is common within the literature (Mills 1956; Domhoff 1967; Zeitlin 1974; Useem 1984), but hard evidence for this thesis is surprisingly limited. Research does show that corporate elites who are instrumental in the formation of interlocking directorates (i.e., multiple directors) are distinctive in terms of their political affiliations and behavior (Useem 1984; Burris 1991; Broyles 1993). However, systematic research using modern methods of network analysis to study the structure and/or behavioral consequences of interlock networks for individual directors is almost entirely lacking (see Bearden and Mintz [1987] and Johnsen and Mintz [1989] for notable exceptions). Overwhelmingly, the empirical research on interlocking directorates has taken the links among firms as the focus of analysis, ignoring the complementary network of links among

\footnotetext{
${ }^{4}$ The distinction between interorganizational and intraclass perspectives on interlocking directorates is fruitfully employed in a number of later studies (Palmer, Friedland, and Singh 1986; Palmer and Friedland 1987; Johnsen and Mintz 1989; Kono et al. 1998; Palmer and Barber 2001). See Mintz (2002) for a comprehensive discussion of the theoretical and empirical questions raised by this distinction.
} 
individual directors created by their common membership on corporate boards.

The present study seeks to broaden the research on interlocking directorates by investigating ties among individual directors and the significance of those ties for the political behavior of individual directors. The case for extending the research on interlocking directorates in this direction is reinforced by two important facts. First, in the terminology of social network analysis, the network of firms linked through directors and the network of directors linked through firms are known as "duals" of one another. It is well established that there is no simple correspondence between the structural properties of a network and its dual (Breiger 1974). This makes any inferences about patterns or processes of cohesion from one network to the other fraught with danger. For example, Bearden and Mintz (1987) show that although banks play a central role in unifying the network of corporations linked through shared directors, bankers themselves do not play a corresponding role in unifying the network of directors linked through corporations.

Second, as Burris (2001) shows with respect to campaign contributions, research based on the political behavior of firms cannot be extrapolated to predict or explain the political behavior of corporate elites associated with those firms, and vice versa. The political action of individuals follows a different logic from the political action of firms as a result of the different legal, institutional, and strategic contexts in which it occurs. For example, as political contributors, firms are generally more interested in buying access for purposes of lobbying, whereas individual corporate elites are more interested in bolstering the election prospects of favored parties and candidates. Hence, research on campaign spending by individual corporate elites, by providing a more direct measure of true partisan preferences, may clarify theoretical questions that remain unresolved in the research based on corporate contributions. For both of these reasons, investigation of the political implications of interlocking directorates should not be limited to the analysis of firms, but should include research on the ties among individual corporate elites and the consequences of those ties for political action.

This study uses data on campaign contributions and methods of network analysis to investigate the consequences of interlocking directorates for the political behavior of individual corporate elites. Using quadratic assignment procedure (QAP) regression, I show that social ties formed through common membership on corporate boards contribute more to political cohesion than presumed commonalities of economic interestssuch as those associated with operating in the same industry or the same geographic region - that are widely cited in the literature as important influences on the politics of corporations and corporate elites. The study 
thus highlights the significance of interlocking directorates, relative to other factors, as potentially important mechanisms of political cohesion within the business community.

\section{DATA AND METHODS}

For this analysis, I constructed a set of similarly ordered matrices representing links through boards of directors and measures of political cohesion among 761 corporate elites. To assemble the sample, I began with the top officers of 1,050 of the largest U.S. corporations in 1980. These included the 500 largest publicly traded industrial firms, the 100 largest service firms, the 50 largest commercial banks, the 50 largest investment banks, the 50 largest insurance firms, the 50 largest diversified finance companies, the 50 largest retailers, the 50 largest transportation firms, the 50 largest utilities, and the 100 largest privately held companies. Individual corporate elites were eligible for inclusion in the sample if they held positions of chairman, CEO, president, or (in the case of investment banks) partner of any of these 1,050 corporations (a total of 1,879 persons).

Following Mizruchi (1992), I operationalized political behavior in terms of contributions to political candidates. Through a careful examination of the Federal Election Commission's list of individual campaign contributors, I identified 1,088 of those top corporate executives who contributed to political candidates or committees in the 1980 election (the same election studied by Mizruchi). Of these 1,088 contributors, 761 made at least one contribution to a candidate for president. These 761 presidential contributors were taken as the sample for the study. ${ }^{5}$

The pattern of political contributions by individual corporate elites differs in several ways from that of the corporate political action committees (PACs) that have been the focus of most recent research on business involvement in campaign finance. For legal and other reasons, aggregate corporate contributions are usually larger than those made by

\footnotetext{
${ }^{5}$ Presidential contributors are not a perfectly random cross-section of the larger sample of 1,879 top corporate officers, although the differences are modest. On average, presidential contributors tend to be associated with slightly larger firms, and they hold slightly more outside directorships. Top executives of firms with high levels of defense contracts are especially likely to be presidential contributors, but otherwise, there are few significant industry differences in the propensity to contribute. Neither are there any pronounced regional differences between contributors and noncontributors. As a precaution, I applied a correction for selection bias to control for any effects associated with nonrandomness, but, as I explain in more detail below, the results of the study remain the same with or without such a correction.
} 
individuals. ${ }^{6}$ In 1980, for example, the average total contribution of 489 PACs operated by the largest U.S. firms was about $\$ 29,000$ (Mizruchi and Koenig 1986, p. 483). By comparison, the average total contribution of the 761 corporate directors in this sample was about $\$ 5,000 .^{7}$ Corporate PAC contributions are also spread across a larger number of candidates and are directed mainly toward congressional races. Individual corporate elites rarely contribute to more than a handful of congressional candidates and direct a larger share of their contributions to presidential candidates and to both party and nonparty committees. ${ }^{8}$ Finally, although corporations are known to contribute to competing candidates in the same race, this is relatively rare. In the case of presidential primaries, however, it is not uncommon for individual corporate elites to contribute to more than one candidate for the same office. ${ }^{9}$ Of the directors in the sample, $38 \%$ contributed to two or more presidential candidates, and $18 \%$ contributed to three or more. This difference is largely a reflection of the distinctive character of presidential primaries as compared with the congressional races that receive the bulk of corporate PAC money. The logic of presidential primaries encourages contributors to hedge their bets by supporting multiple candidates who represent a similar political viewpoint, by switching support from one candidate to another depending upon the

${ }^{6}$ Legally, individuals were limited to $\$ 50,000$ in total contributions in the 1980 election. Corporate PACs were restricted to $\$ 10,000$ per candidate (primary and general election combined) but had no limit on total contributions.

${ }^{7}$ This might make it appear that contributions by individual corporate elites are politically less important than those made by corporations, but it should be remembered that there are many times more corporate elites who contribute to political campaigns than there are corporations. Overall, contributions by business elites and other wealthy individuals are the single largest source of money for political campaigns. This is especially true for presidential primary campaigns, where PACs play a negligible role, and $70 \%-90 \%$ of the money raised by candidates comes from large individual contributions (Brown, Powell, and Wilcox 1995, p. 8). In congressional races, large individual contributions account for roughly $35 \%-40 \%$ of the money raised, compared with 6\%-10\% raised from corporate PACs (Federal Election Commission 2001). I cannot say for certain what share of these large contributions comes from corporate elites, although the fact that $46 \%$ of those making contributions of $\$ 200$ or more report annual incomes in excess of $\$ 250,000$ suggests that high-ranking corporate officers are well represented among this group (Green et al. 1998).

${ }^{8}$ By nonparty committees, I refer here specifically to ideological PACs of the kind that clearly aligned with one or the other of the two major parties. Corporate elites also make contributions to their own company or industry PACs, but these are excluded from this analysis because of the difficulty in assigning them any clear partisan meaning.

${ }^{9}$ Since 1976, presidential candidates who accept public funding in the general election are precluded from taking further private donations after they have received their party's nomination. Hence, it is during the prenomination primary campaign that individual corporate elites make their contributions to presidential candidates. 
shifting fortunes of candidates over the long primary campaign, or by seeking to minimize the potential stakes of the general election by contributing to their preferred candidate(s) in each of the two major parties.

For each of the 289,180 dyads in the study, I constructed three measures of similarity of political behavior. The first measures the similarity between corporate directors in terms of the percentage of their total political contributions going to each of the two major parties. The similarity of party support between directors $i$ and $j$ (denoted by $P_{i j}$ ) is given by the expression:

$$
P_{i j}=1-\left|r_{i}-r_{j}\right|
$$

where $r_{i}$ is the proportion of director $i$ 's total contributions that went to Republican Party candidates or committees, and $r_{j}$ is the proportion of director $j$ 's total contributions that went to Republican Party candidates or committees. This measure ranges from zero (least similar) to one (most similar).

The second and third measures focus exclusively on contributions to presidential primary candidates. The presidential contest receives by far the most donations by individual corporate elites and is the only race in which a sufficient number of individuals contribute to allow for a detailed analysis of patterns of support for identical or opposing candidates. Compared with other presidential elections, the 1980 election is particularly well suited for revealing political differences among corporate elites. The fact that there was neither an incumbent nor a clear front-runner among Republican presidential hopefuls, combined with the vulnerability of the Democratic incumbent (Jimmy Carter), encouraged a large and ideologically diverse field of Republican candidates to compete for financial support from the business community (John Anderson, ${ }^{10}$ Howard Baker, George Bush, John Connally, Philip Crane, Robert Dole, Benjamin Fernandez, and Ronald Reagan). Having a Democratic president up for reelection also served to separate the hard-core Republican supporters from the more pragmatic ones who, despite their Republican sympathies, were not averse to contributing some money to Democratic candidates, especially if they were incumbents. Finally, Carter's vulnerability within his own party brought two popular Democratic challengers into the race

${ }^{10}$ Better remembered for his third-party candidacy in the 1980 general election, John Anderson was initially a candidate for the Republican presidential nomination. 
(Jerry Brown and Ted Kennedy), creating additional choices for the minority of corporate elites who traditionally supported Democrats. ${ }^{11}$

The similarity in corporate directors' contributions to presidential candidates was measured in two ways. The first measure counts the number of instances in which directors contributed to the same presidential candidate, controlling for variation in the total number of presidential candidates supported by each dyad of directors. The number of standardized matches in presidential contributions (denoted by $S_{i j}$ ) is given by the expression

$$
S_{i j}=x_{i j} / \sqrt{x_{i} x_{j}}
$$

where $x_{i j}$ is the number of presidential candidates supported jointly by directors $i$ and $j, x_{i}$ is the total number of presidential candidates supported by director $i$, and $x_{j}$ is the total number of presidential candidates supported by director $j$. This measure ranges from zero (no matches in the candidates supported) to one (only matching candidates supported). ${ }^{12}$ The second measure is the Pearson correlation for each dyad of directors between the $1 \times 11$ vectors representing the amount of their contributions to each of 11 presidential candidates (Anderson, Baker, Brown, Bush, Carter, Connally, Crane, Dole, Fernandez, Kennedy, and Reagan). There

\footnotetext{
${ }^{11}$ It goes without saying that, in order to identify sources or mechanisms of political cohesion within the business community, we require data on a type of political behavior for which there is not too much unity, since it is only through the variance in patterns of behavior that the causes or correlates of cohesion can be identified. In this respect, presidential primary contributions are particularly well suited for exploring political cohesion within the business community, since they accentuate modest differences in political preferences, even when a substantial majority of corporate elites are relatively unified in their support for Republican over Democratic candidates.

${ }^{12}$ The number of matches is standardized to ensure that similarity is measured independently of variation in the number of candidates supported - that is, to make sure that two directors who contribute to multiple candidates will not appear more similar simply because of an increase in the random likelihood of matching candidates as the total number of supported candidates increases. This index is identical to the measure used by Mizruchi (1992) to measure the similarity of candidates supported by corporate PACs, and is also similar to one employed by Mariolis (1975) to measure the degree of overlap among corporate boards of different sizes. As a practical matter, the variation in the number of presidential candidates supported by individual corporate elites is smaller than the variation in the number of candidates supported by corporate PACs, so the effects of standardization are modest in this study. A simple count of the number of matches in the candidates supported does not yield significantly different results from the standardized measure employed here.
} 
are different strengths and weaknesses to each of these measures, although empirically they are highly correlated and yield similar results. ${ }^{13}$

Standard and Poor's Register of Corporations, Directors and Executives (1980) and Marquis' Who's Who in Finance and Industry (1979-80) were used to identify the corporate directorships held by each of the 761 individuals in the sample. With these data, I computed direct and indirect board ties among the 289,180 dyads formed by these 761 individuals. Approximately $62 \%$ of the corporate elites in the study had a direct tie to at least one top executive of another firm through their joint membership on a corporate board. Of the 289,180 dyads, roughly half of $1 \%$ of the total were linked through a direct board tie. ${ }^{14}$ Another $2.7 \%$ of the dyads were linked indirectly through a third party to whom both individuals were directly tied.

As control variables, and also to provide benchmarks against which to assess the strength of any political effects associated with directorship ties, I constructed three additional independent variables for each dyad of directors: shared firm, common industry, and geographic proximity. Shared firm is a dichotomous variable which is coded one when two directors' primary executive position is with the same firm, and zero otherwise. There is general agreement that ties of this kind should be conducive to similarity of political behavior. Hence, they provide a yardstick against which to measure the effects of directorship ties to executives of other firms. Common industry is a dichotomous variable that is coded one if both directors' main executive position is with firms that operate in the same primary industry, and zero otherwise. Here, I used Moody's Manuals (Moody's Investors Service 1980) and Ward's Directory of 55,000 Largest U.S. Corporations (Ward Publications 1981) to assign firms to 33 industries, roughly equivalent to two-digit Standard Industrial Classification (SIC) categories. Geographic proximity is a dichotomous variable

\footnotetext{
${ }^{13}$ The measure of standardized matches in the candidates supported has the advantage of not treating noncontributions as instances of similar behavior, but it has the disadvantage of ignoring variation in the relative size of contributions. The Pearson correlation measure gives due weight to variation in the relative size of contributions, but treats matching contributions of $\$ 0$ (i.e., noncontributions) as indicators of similar behavior. The correlation between the two measures is $0.93(P<.001)$. As one would expect, both measures of similar presidential contributions are also positively associated with similarity of party support, although the correlation here is more modest $(r=$ $.29 ; P<.001)$. This is because most of the variation in corporate directors' contributions to presidential candidates occurs among candidates of the same party (namely, Republicans) rather than between parties.

${ }^{14}$ Here I refer only to directorship ties that link officers of two different firms, rather than two officers of the same firm. There is a slight undercounting of directorship ties because interlocks were counted only if they were created through the boards of any of the largest 1,050 U.S. corporations. To limit the data collection to a manageable scale, ties created through the boards of smaller firms were not counted.
} 
that is coded one if both directors' main executive position is with a firm headquartered in the same state, and zero otherwise. ${ }^{15}$

Industry and region are routinely cited by pluralist theorists as important axes of interest group formation and competition within the business community (Truman 1951; Dahl 1961; Berle 1963; Rose 1967; Epstein 1969; Vogel 1989; Smith 2000). According to this view, for example, protectionist tariffs are likely to be favored by threatened manufacturing industries but opposed by other business sectors that would be forced to pay higher prices for imported goods or fear retaliation that would limit their access to foreign markets. Similarly, increased military spending might be favored by defense contractors but produce fiscal consequences that would be costly to other industries. Regional political alignments are understood in a similar fashion. State and regional business coalitions are seen as pitted against one another in competition for federal programs or expenditures that would tend to strengthen the local economies in which they operate. State and local variations in tax, labor, and regulatory laws also mean that many kinds of federal legislation will have differential impact on (and may receive differential support from) firms operating in different geographic locales.

Pluralists are not alone in viewing industry and region as important bases of political alignment within the business community. Industry and region are also central to those variants of elite and class cohesion theory that acknowledge political competition between "capitalist class segments" (Sale 1975; Dye 1976; Zeitlin, Neuman, and Ratcliff 1976; Davis 1981; Ferguson and Rogers 1986; Domhoff 1987; Ferguson 1995). For example, distinctive politics are often identified with financial and industrial capital or with "Yankee" (northern) and "cowboy" (southern and western) business interests. Research on campaign contributions by individual corporate elites reveals significant differences in political partisanship by industry and region (Overacker 1933, 1937, 1941, 1945; Heard 1960; Domhoff 1972; Allen and Broyles 1989; Ferguson 1995; Webber 2000; Burris 2001). Additional research shows that regional variation in presidential primary contributions is accentuated by the reliance of many presidential candidates on contributions from longtime supporters in their home states (Brown et al. 1995). Hence, the consensus of both the theoretical and empirical literature is that common industry and geographic proximity

\footnotetext{
${ }^{15}$ In all but a few cases, corporate officers reside in the same state in which the firm with which they are affiliated has its headquarters. The choice between their state of residence and the state in which their firm is headquartered has negligible effects on the analysis.
} 
ought to be associated with similarity of political contributions among corporate elites. ${ }^{16}$

Finally, to broaden the analysis of directorship ties and to provide an additional benchmark against which to assess the political effects of ties formed through corporate boards, I included one measure of ties among corporate elites that are created through their common membership on noncorporate boards of directors. In addition to their corporate directorships, high-ranking executives often serve as directors of noncorporate organizations, including foundations, think tanks, business lobbies, trade associations, universities, charities, and civic associations. Like interlocking corporate directorates, these noncorporate boards provide the institutional basis for an extensive network of social ties among corporate elites-ties that could be instrumental in facilitating political cohesion. Of the myriad types of noncorporate boards of directors, arguably the most important from a political standpoint are those of leading policyplanning organizations like the American Enterprise Institute, the Brookings Institution, and the Council on Foreign Relations. Whereas the skeptic might argue that corporate boards tend to be narrowly concerned with economic performance and are, therefore, unlikely to facilitate political consensus, it is less plausible to argue that common membership on the boards of policy-planning organizations (whose raison d'être is the promotion of elite consensus on policy issues) is inconsequential for political cohesion (Domhoff 1970; Burch 1983; Peschek 1987; Smith 1991; Burris 1992; Dye 2001). Hence, ties formed through policy-planning boardswhere the prima facie case for political cohesion is compelling-provide another benchmark for assessing the significance of any political effects associated with corporate board ties. To measure the presence of these ties, I constructed a dichotomous variable that indicates whether each

\footnotetext{
${ }^{16}$ In this study, I treat geographic proximity and common industry as shared characteristics that are likely to be associated with a coincidence of economic interests. However, such variables could also be construed as weak proxies for social network ties, since corporate elites within the same state or industry are more likely to have social ties to one another than they are to corporate elites in other states or industries (Palmer et al. 1986; Palmer and Friedland 1987). Past research shows that interlocking corporate directorates are, themselves, partly organized on a regional basis (Allen 1974, 1978; Koenig and Sonquist 1977; Mizruchi 1982; Mintz and Schwartz 1985; Bearden and Mintz 1985, 1987; Johnsen and Mintz 1989; Kono et al. 1998). Consistent with this research, using the method of QAP correlation (explained below), I found that corporate directorship ties among individual corporate elites are modestly, but significantly, associated with geographic proximity $(r=.09 ; P<.001)$.
} 
dyad of directors is linked through their joint membership on the boards of any of 20 leading policy-planning organizations. ${ }^{17}$

Table 1 reports descriptive statistics on the dependent and independent variables employed in the study. Note that all of the independent variables are dichotomous, and all of the dependent variables are continuously distributed and roughly interval scaled. Ordinary least squares (OLS) regression is an appropriate method with these kinds of data. ${ }^{18}$ However, the fact that the 289,180 dyads are created by multiple relations among only 761 corporate elites means that the observations are not statistically independent. This creates potential problems of autocorrelation in the regression results that are not easily handled by conventional regression techniques.

This study uses QAP regression to overcome these problems associated with autocorrelation (Krackhardt 1987, 1988). The method was implemented using the UCINET network analysis program (Borgatti, Everett, and Freeman 1999). QAP regression begins by calculating, in the usual fashion, OLS coefficients for all the independent variables in the regression, but then it uses a nonparametric technique to estimate the probabilities of these coefficients. This is done by randomly permuting (i.e., reordering) all the rows and columns of the dependent variable matrix and then recalculating the regression coefficients. In effect, this may be understood as a simulation that retains the structure of dyadic relations among the actors but rearranges the individuals assigned to each set of values. The process is repeated a large number of times (in this study

\footnotetext{
${ }^{17}$ The 20 organizations are the American Enterprise Institute, the Aspen Institute, the Brookings Institution, the Business Council, the Business Roundtable, the Cato Institute, the Chamber of Commerce of the United States, the Conference Board, the Committee for Economic Development, the Council on Foreign Relations, the Heritage Foundation, the Hoover Institution, the Hudson Institute, the Institute for Contemporary Studies, the Manhattan Institute, the National Association of Manufacturers, the RAND Corporation, the Rockford Institute, the Trilateral Commission, and the Urban Institute. In $94 \%$ of the cases where corporate elites shared a policy board directorship, they had only one such tie; $5 \%$ of the time, they shared two such ties; and $1 \%$ of the time, they shared three such ties. A continuous measure based on the total number of shared policy board directorships does not yield significantly different results from a simple dichotomous measure.

${ }^{18}$ Note also that the first two dependent variables are bounded by 0 and 1 , and the third by -1 and 1 . In such situations, it is customary for purposes of regression to apply a logit transformation to the dependent variable to ensure that the predicted values do not fall outside the bounds of the valid range of the dependent variable. With the regression method used in this study (described in the next paragraph), this is less of a problem because the probabilities of the regression coefficients are estimated in a nonparametric fashion. Moreover, in the regressions that follow, none of the predicted values of any dependent variable fall outside these bounds. Because of the difficulties in interpreting regression coefficients associated with logit-transformed data, I decided to leave the dependent variables in their raw form.
} 
TABLE 1

Descriptive Statistics on Dependent and Independent Variables

\begin{tabular}{|c|c|c|c|c|}
\hline Variable & Min & Max & Mean & $\mathrm{SD}$ \\
\hline \multicolumn{5}{|l|}{ Dependent variables: } \\
\hline $\begin{array}{l}\text { Similarity in percent of contributions } \\
\text { to parties }\end{array}$ & .00 & 1.00 & .658 & .349 \\
\hline $\begin{array}{l}\text { Standardized matches in presidential } \\
\text { contributions } \ldots \ldots \ldots \ldots \ldots \ldots \ldots \ldots\end{array}$ & .00 & 1.00 & .294 & .364 \\
\hline $\begin{array}{l}\text { Correlation between presidential } \\
\text { contributions } \ldots \ldots \ldots \ldots \ldots \ldots \ldots \ldots\end{array}$ & -.54 & 1.00 & 183 & .423 \\
\hline \multicolumn{5}{|l|}{ Independent variables: } \\
\hline Shared firm $\ldots \ldots \ldots \ldots \ldots \ldots \ldots \ldots$ & .00 & 1.00 & .001 & .025 \\
\hline Common industry $\ldots \ldots \ldots \ldots \ldots \ldots$ & .00 & 1.00 & .040 & .196 \\
\hline Geographic proximity $\ldots \ldots \ldots \ldots \ldots$ & .00 & 1.00 & .075 & .264 \\
\hline Policy-planning board interlock ...... & .00 & 1.00 & .003 & .057 \\
\hline Direct corporate board interlock ..... & .00 & 1.00 & .004 & .066 \\
\hline Indirect corporate board interlock ... & .00 & 1.00 & .027 & .163 \\
\hline
\end{tabular}

Note. $-N=289,180$ dyads among 761 corporate directors.

2,000 times) to provide an estimate of the distribution of all possible coefficients that are consistent with the structure of the data. This distribution is then used to estimate the probability that each coefficient could have achieved a value as extreme as the observed value simply by chance. For example, if only 100 out of 2,000 permutations of the matrix yield regression coefficients as large as the observed value, then this indicates that the probability that the actual coefficient could be the result of random sampling error is about 0.05. Simulation studies indicate that, regardless of the degree of autocorrelation, QAP regression yields unbiased parameter estimates that can be interpreted in the same manner as those of a standard regression (Krackhardt 1988). ${ }^{19}$

\section{FINDINGS}

Table 2 reports the coefficients for three regression models that estimate the effects of shared firm, common industry, geographic proximity, and directorship ties on each of three measures of similar political behavior.

\footnotetext{
${ }^{19}$ Other approaches to regression with autocorrelated network data are also possible, mainly borrowed from the techniques used in time-series analysis or with spatially autocorrelated data. See Krackhardt (1988) and Mizruchi (1992, pp. 111-16) for a discussion of the advantages of QAP over alternative methods. Among the chief advantages of QAP are its computational feasibility with very large networks and the fact that it solves the problem of potentially biased parameter estimates in a manner that retains the row/column interdependence that is an essential property of network data.
} 
TABLE 2

Regression of Political Cohesion on Measures of Shared Traits and DiRECTORSHIP TIES: UnSTANDARDIZED REgRESSION COEFFICIENTS

\begin{tabular}{|c|c|c|c|}
\hline \multirow[b]{2}{*}{ INDEPENDENT VARIABLE } & \multicolumn{3}{|c|}{ DEPENDENT VARIABLE } \\
\hline & $\begin{array}{c}\text { Party } \\
\text { Contribution } \\
\text { Similarity }\end{array}$ & $\begin{array}{c}\text { Presidential } \\
\text { Contribution } \\
\text { Matches }\end{array}$ & $\begin{array}{c}\text { Presidential } \\
\text { Contribution } \\
\text { Correlation }\end{array}$ \\
\hline Shared firm & $\begin{array}{c}.104 \\
(.000)\end{array}$ & $\begin{array}{c}.186 \\
(.000)\end{array}$ & $\begin{array}{c}.250 \\
(.000)\end{array}$ \\
\hline Common industry & $\begin{array}{c}.005 \\
(.201)\end{array}$ & $\begin{array}{c}.014 \\
(.005)\end{array}$ & $\begin{array}{c}.016 \\
(.004)\end{array}$ \\
\hline Geographic proximity $\ldots \ldots \ldots \ldots \ldots$ & $\begin{array}{c}.004 \\
(.297)\end{array}$ & $\begin{array}{c}.017 \\
(.019)\end{array}$ & $\begin{array}{c}.017 \\
(.021)\end{array}$ \\
\hline Policy-planning board tie $\ldots \ldots \ldots \ldots$ & $\begin{array}{c}.063 \\
(.066)\end{array}$ & $\begin{array}{l}.105 \\
(.001)\end{array}$ & $\begin{array}{l}.105 \\
(.002)\end{array}$ \\
\hline Direct corporate board tie $\ldots \ldots \ldots$. & $\begin{array}{c}.101 \\
(.000)\end{array}$ & $\begin{array}{c}.099 \\
(.000)\end{array}$ & $\begin{array}{c}.119 \\
(.000)\end{array}$ \\
\hline Indirect corporate board tie ....... & $\begin{array}{c}.102 \\
(.000)\end{array}$ & $\begin{array}{c}.098 \\
(.000)\end{array}$ & $\begin{array}{c}.113 \\
(.000)\end{array}$ \\
\hline Intercept $\ldots \ldots \ldots \ldots \ldots \ldots \ldots \ldots$ & .654 & .288 & .177 \\
\hline$R^{2}$ & .003 & .003 & .003 \\
\hline
\end{tabular}

Note.-QAP probabilities in parentheses. $N=289,180$ dyads among 761 corporate directors.

Shown here are the unstandardized OLS coefficients with QAP probabilities in parentheses. Before I discuss the substantive significance of these results, it is worth saying a few words about what should not be given undue importance in the figures shown in table 2. First, the fact that the $R^{2}$ for each of the regressions is quite small should neither come as a surprise nor be a matter of concern. The fact that the directorship ties that are the main focus of interest are present only in a tiny percent of the 289,180 dyads in the sample guarantees that the explained variance associated with these ties will be small, simply as a result of the radically different distributions of the dependent and independent variables. For example, even if all of the dyads of corporate elites who are linked by a direct board interlock contributed identical amounts to identical presidential candidates, direct interlocks would still explain less than $2 \%$ of the variance in either measure of similar presidential contributions ${ }^{20} \mathrm{Com}-$ pared against this yardstick, the fact that the actual regression results

\footnotetext{
${ }^{20}$ This simulation is done by substituting a maximum possible similarity score of 1.0 on the dependent variable for each dyad of interlocked directors, leaving the similarity scores on the other dyads unchanged and reestimating the regression model. The maximum possible explained variance on the similarity of party contributions is comparable in magnitude.
} 
explain roughly a third of a percent of the variance in the dependent variables does not appear unduly small.

Second, too much importance should not be given to the mere fact that the coefficient associated with a particular independent variable achieves a high level of statistical significance. With a sample this large, small effects can still achieve a high level of statistical significance. The important point is not whether one independent variable is statistically significant while another is not, but the relative size of the unstandardized coefficients associated with these variables. ${ }^{21}$ Because all of the independent variables are measured in an identical (dichotomous) fashion, denoting the presence or absence of a specific type of shared trait or social tie, the unstandardized regression coefficients provide a straightforward way of comparing the average impact of each kind of shared trait or social tie on each measure of political cohesion.

In terms of the issues that are the focus of this study, the most impressive finding shown in table 2 is the relatively large magnitude of the coefficients associated with directorship ties. The cohesive effects of directorship ties between executives of different firms compare favorably with the effects of holding high executive office within the same firm. The coefficients associated with shared firm ties are consistently larger, but not dramatically so. For similarity of party contributions, they are only a few percentage points larger than the coefficients associated with directorship ties outside the home firm. For the measures of similar presidential contributions, they are roughly twice as large.

Importantly, the cohesive effects of directorship ties far exceed any effects associated with common industry or geographic proximity. Measuring political behavior in terms of party contributions, the fact that two corporate elites are tied, either directly or indirectly, through a corporate board interlock has, on average, roughly 20-25 times the impact on their similarity of political behavior as either common industry or geographic proximity. To put this in more concrete terms: if we were to choose two corporate elites at random, the expected difference in their percentage of contributions to Republicans or Democrats would be roughly 34 percentage points. Randomly selecting pairs of corporate elites from the same state or whose primary affiliation is with firms in the same industry, we

\footnotetext{
${ }^{21}$ There is another reason for not placing excessive importance on tests of significance. The data employed in this study are not based on a random sample. Rather, they are more appropriately viewed as a population of dyads among all the top officers of the largest 1,050 firms who contributed to presidential candidates in 1980. With data of this sort, significance tests remain useful as a heuristic device for interpreting the strength of relations among variables, but they do not have the usual meaning of providing an estimate of the probability that the results could be caused by random sampling error.
} 
would not expect this gap to close by more than half a percentage point. However, randomly selecting pairs of corporate elites who are tied through a corporate board interlock, we would expect this gap to close from 34 to about 24 percentage points.

Similar results are shown for the two measures of similarity of presidential contributions. For these measures, directorship ties have, on average, five to eight times the impact on similarity of political behavior as either common industry or geographic proximity. In more concrete terms: for two directors chosen at random, the mean likelihood that a presidential candidate supported by one director will also be supported by the other is approximately $0.29 .^{22}$ Randomly selecting pairs of directors from the same state or whose primary affiliation is with firms in the same industry would increase this likelihood to between 0.30 and 0.31 . Randomly selecting pairs of directors who are tied through a corporate board interlock would increase this likelihood from 0.29 to 0.39 .

To test the robustness of these results, I examined a number of alternative measures of common industry and geographic proximity. For example, I constructed a measure of common industry based on less highly aggregated industries (equivalent to three-digit SIC categories). I constructed measures of geographic proximity based on both smaller (metropolitan) and larger (regional) geographic units. The substitution of these alternative measures yields small changes in the magnitudes of some regression coefficients, but in no case does it significantly diminish the disparity between the relatively strong effects of directorship ties and the comparatively weak effects of common industry and geographic proximity.

Additional control variables were also added to see what effects, if any, these might have on the results. Previous research indicates that status characteristics, such as ethnicity (Jewish/non-Jewish), elite educational background, and listing in the Social Register, influence the political partisanship of individual corporate elites (Domhoff 1972; Allen and Broyles 1989; Burris 2001). It is therefore possible that similarity in terms of such status characteristics might contribute to similarity of political behavior. To maintain comparability with Mizruchi's study, I refrained from introducing variables of this type into the models shown in table 2. Such variables have meaning only at the individual level and not at the level of the firm. In parallel analyses, however, controls for shared ethnicity, common attendance at elite colleges and universities, and joint listing in the Social Register were added. More often than not, these variables do

\footnotetext{
${ }^{22}$ Here I refer to the geometric mean of the probability that any candidate supported by director $i$ will also be supported by director $j$, and the probability that any candidate supported by director $j$ will also be supported by director $i$.
} 
have significant effects on similarity of political behavior, but they are sufficiently orthogonal to the other independent variables that their inclusion has only a modest impact on the coefficients associated with those variables and does not alter the main results shown in table 2. Including these controls in the estimation of similarity of party contributions, the coefficients associated with corporate directorship ties remain 15-25 times as large as those associated with common industry or geographic proximity. Including them in the estimation of similarity of presidential contributions, the coefficients for corporate directorship ties remain six to eight times as large as those associated with common industry or geographic proximity. ${ }^{23}$

Further, as a check against the possibility that these results are partly an artifact of sample selection, I reestimated the three regression equations in table 2 with a correction for sample selection bias. The usual practice in the research that uses data on campaign contributions to measure political partisanship is to construe the population under study as restricted to those large corporations (or officers of large corporations) who contribute to political parties or candidates (Mizruchi 1992, p. 112). The foregoing discussion is based on this assumption; hence, I would not want to claim that these findings are generalizable to other (latent or unmeasured) types of political partisanship by corporate elites outside of this population. Nevertheless, our confidence in these results can still be enhanced by exploring the question of how they might differ were we to construe the population of 289,180 dyads among 761 presidential contributors as a nonrandom sample of the larger population of $1,764,381$ dyads among all 1,879 top officers of the largest 1,050 firms. From this perspective, similarity with respect to political contributions can be viewed as a joint outcome of (1) the decision of whether or not to contribute, and (2) among those who contribute, the decision of which parties or candidates to support. In the nomenclature used to discuss sample selection, the first process is said to be estimated in terms of a "selection model," and the second is estimated in terms of a "substantive model."

To reestimate the regression coefficients under these assumptions, I computed a full maximum likelihood estimation of the Heckman selection model (Heckman 1979; Breen 1996; Greene 2000). The independent variables in the substantive regression models are the same as in table 2. The selection model includes all three types of directorship ties plus two additional variables known to increase the likelihood of making a political contribution: firm size (measured as the geometric mean of the sales of the two firms that serve as the primary employer of the directors in each

\footnotetext{
${ }^{23}$ Detailed results of the revised regression models that include controls for similar status characteristics are available from the author upon request.
} 
dyad) and defense contracts (measured in an analogous manner). Consistent with previous research (Useem 1984), multiple directors are more likely than single directors to be political contributors. The coefficients associated with directorship ties are therefore positive in the selection model. Thus, if we interpret positive matches on the decision to contribute as a measure of similar political behavior, then director interlocks can be viewed as increasing the likelihood of similarity in this sense.

In the reestimation of the substantive regression models for the three original measures of political cohesion, the coefficients associated with direct and indirect corporate interlocks decline by approximately onequarter. The coefficients associated with common industry and geographic proximity decline by roughly the same proportion. Consequently, the main findings revealed by the regression estimates shown in table 2 remain essentially unchanged. On the measure of similarity of party contributions, directorship ties have 20-30 times the effect on political cohesion as either common industry or geographic proximity. On the measures of similarity of presidential contributions, directorship ties have five to seven times the effect on political cohesion as either common industry or geographic proximity. Hence, the disparity between the relatively strong effects of directorship ties and the comparatively weak effects of common industry and geographic proximity does not appear to be attributable to sample selection bias. ${ }^{24}$

Apart from this basic finding, several other patterns shown in table 2 deserve comment. First, in contrast to Mizruchi's (1992) finding that similarity of political contributions among corporations is mainly associated with indirect interlocks, this study shows that both direct and indirect ties are highly significant and roughly comparable in the magnitude of their effects on political cohesion among individual corporate elites. The implications of this finding will be examined in greater detail in the following section of the article.

Second, for all three measures of political cohesion, the political effects

\footnotetext{
${ }^{24}$ These results should be viewed with a degree of caution. As is amply demonstrated in the literature, neither the widely used Heckman model nor any other technique guarantees rescue from potential problems of selection bias (Berk 1983; Berk and Ray 1982; Hartman 1991; Nelson 1984; Stolzenberg and Relles 1990, 1997; Winship and Mare 1992). Almost any population can always be reconceptualized as a nonrandom sample of an even larger population. The precision of the Heckman estimator is sensitive to the specific variables chosen for the selection equation and, thus, on the adequacy of our implicit theory of the selection process. Under a variety of common (but not easily specified) circumstances, correction for selection bias can worsen rather than improve estimates. Moreover, the literature provides little if any guidance or practical experience in attempting to apply a correction for selection bias to dyadic data. Detailed results of the Heckman estimation are available from the author upon request.
} 
of corporate board ties are roughly as great as those of ties created through the boards of leading policy-planning organizations. ${ }^{25}$ This is an impressive finding, considering the important role that such policy-planning organizations are believed to play in forging elite political consensus (Domhoff 1970; Burch 1983; Peschek 1987; Smith 1991; Burris 1992; Dye 2001).

Finally, whereas the corporate interlock measures are quite robust in their effects across all three measures of political cohesion, the same is not true for the measures of common industry and geographic proximity. As expected, these two variables are positively associated with similarity of presidential contributions. Contrary to expectations, however, when similarity of political behavior is measured in terms of the percentage of contributions to each of the two major parties, neither common industry nor geographic proximity has a marked effect on political cohesion. Although the coefficients are in the expected direction, their magnitude is so small as to be statistically insignificant even in this very large sample. ${ }^{26}$ This finding, too, stands in contrast to the results of Mizruchi's (1992) study of corporate campaign spending, which shows that geographic proximity (although not common industry) has a significant positive effect on similarity of party support among corporations.

\section{INTERLOCKING DIRECTORATES AS EXTENDED CHAINS OF INDIRECT TIES}

To this point in the analysis, I have focused mainly on the effects of direct board ties or, at most, indirect ties of a distance of two. This has been necessary to isolate the specific relations through which interlocking directorates are created and to assess the political effects of those relations at their point of origin. It should be emphasized, however, that the purported significance of interlocking directorates is not simply their potential to create a tie between director $i$ and director $j$ that may have consequences for the political behavior of those two individuals. As understood by elite and class cohesion theorists, interlocking directorates are significant because they form an extended chain or network of ties that increases the potential for political cohesion across an entire class of individuals,

\footnotetext{
${ }^{25}$ In the regression shown in table 2, the effect of policy-planning board ties on similarity of political party contributions is somewhat weaker than the effects of either direct or indirect corporate board ties. However, at the zero-order level, the effects of these three kinds of directorship ties are more closely comparable in magnitude, and all three are statistically significant. There is a modest correlation between policy board ties and both direct corporate interlocks $(r=.05 ; P<.001)$ and indirect corporate interlocks $(r=.08 ; P<.001)$, so that the variance explained by the former declines once the latter two are included in the regression.

${ }^{26}$ This is true not only in the multivariate model, but also at the zero-order level.
} 
not all of whom are directly linked to one another. Showing that directorship ties are associated with similarities of political behavior for individual dyads of corporate elites enhances the plausibility of this argument, but it is not sufficient of itself. It must also be shown that the extended chain or network of directorship ties is sufficiently dense and far reaching to encompass a substantial portion of the leadership group of the business community, and it must be shown that the cohesive effects of directorship ties remain robust even as one moves several links down this chain.

By examining the effects of indirect ties on similarity of political behavior, I have already taken a first step toward addressing these larger issues. The fact that direct and indirect ties are shown to have substantially equivalent effects on similarity of political behavior demonstrates that the mechanisms by which directorship ties facilitate political cohesion remain operative at a distance of at least two links down the chain of person-to-person relations. Thus, if director $i$ and director $j$ are members of the same corporate board, not only are they likely to exhibit similarities of political behavior with one another, but each is likely to exhibit similarities of political behavior with any third corporate elite with whom the other shares a board membership. This raises the interesting and important question of whether or not similarities of political behavior can also be traced at even greater distances along the extended chain of directorship ties.

To examine this question, I created a series of dummy variables representing the minimum number of links required to connect each dyad of directors in the sample. Just how far do such chains of indirect ties extend across this group of politically active top executives of large corporations? As noted earlier, roughly half of $1 \%$ of the 289,180 dyads in the sample are directly linked through a common board membership; adding indirect ties (i.e., ties with a distance of two links) increases the number of linked dyads to roughly $3 \%$ of the sample. Approximately $12 \%$ of the dyads are linked at a distance of three or less, $26 \%$ are linked at a distance of four or less, $37 \%$ are linked at a distance of five or less, and $42 \%$ are linked at a distance of six or less. Hence, even though direct board ties among top corporate officers comprise only a tiny percentage of the dyads in the sample, a substantial plurality of the directors in the sample are connected to one another when indirect ties of four or more links are counted. ${ }^{27}$

\footnotetext{
${ }^{27}$ These results should come as no surprise, given the extensive research demonstrating the high likelihood of being able to connect any two members of most relatively sparse, naturally occurring social networks through chains of six or fewer links (Watts 1999). Note, however, that these figures underestimate the full extent of indirect ties within
} 
Table 3 shows the results of three regression models that estimate the effects of these increasingly distant indirect ties on each of three measures of similar political behavior, again controlling for shared firm, common industry, geographic proximity, and policy board ties. Of course, if direct ties are associated with similar political behavior, then indirect ties will necessarily share in that association. If director $i$ is similar to director $j$, and director $j$ is similar to director $k$, then directors $i$ and $k$ will also share a degree of similarity. But the strength of the latter association should drop off exponentially if it is nothing more than a chance artifact of the underlying direct ties. As can be seen from table 3, this is not the case. For all three measures of similarity of political behavior, there is a gradual decline in political cohesion as one moves from proximate to more distant ties. Nevertheless, in each case, indirect ties up to a distance of four or five links have substantial effects on political cohesion, and the effects of even the most distant ties far exceed those associated with common industry or geographic proximity. ${ }^{28}$

To present this in more concrete terms, we may compare the expected degree of political similarity between randomly selected pairs of directors at varying distances from one another. As noted earlier, if we were to select randomly pairs of directors who are connected through ties of one or two links, the expected difference in their percentage of contributions to Republicans or Democrats would be 24 percentage points. Randomly selecting pairs of directors whose most direct connection is through ties of three or four links, the expected difference in their percentage of contributions to Republicans or Democrats would be 27 percentage points. At a distance of five links the expected difference would be 29 percentage points, at six links it would be 34 percentage points, and at greater than six links it would be 39 percentage points.

A similar pattern exists for presidential contributions. If we were to select randomly pairs of directors who are connected through ties of one

the director interlock network because we are dealing here not with the entire network, but with a subset of top executives. The indirect ties between the directors in our sample would undoubtedly have been shorter and more numerous had we been able to calculate them on the basis of the entire boards of the largest 1,050 U.S. firms. However, this would have required dealing with a matrix of roughly 300 million dyads - a task that poses near-insuperable obstacles in terms of both data collection and computational ability.

${ }^{28}$ As I did for the regression models in table 2, I also reestimated the three regression models in table 3, applying Heckman's (1979) correction for sample selection bias. Again, the results remain essentially unchanged. There is no substantial decline in the coefficients associated with corporate directorship ties. The size of these coefficients declines monotonically as one moves from more proximate to more distant ties. And the effects associated with even the most distant directorship ties far exceed those associated with common industry or geographic proximity. 
TABLE 3

Regression of Political Cohesion on Measures of Shared Traits and Directorship Ties of Increasing Distance: Unstandardized REgression COEFFICIENTS

\begin{tabular}{|c|c|c|c|}
\hline \multirow[b]{2}{*}{ INDEPENDENT VARIABLE } & \multicolumn{3}{|c|}{ DEPENDENT VARIABLE } \\
\hline & $\begin{array}{c}\text { Party } \\
\text { Contribution } \\
\text { Similarity }\end{array}$ & $\begin{array}{c}\text { Presidential } \\
\text { Contribution } \\
\text { Matches }\end{array}$ & $\begin{array}{c}\text { Presidential } \\
\text { Contribution } \\
\text { Correlation }\end{array}$ \\
\hline Shared firm & $\begin{array}{c}.144 \\
(.000)\end{array}$ & $\begin{array}{c}.212 \\
(.000)\end{array}$ & $\begin{array}{c}.280 \\
(.000)\end{array}$ \\
\hline Common industry & $\begin{array}{c}.003 \\
(.261)\end{array}$ & $\begin{array}{c}.013 \\
(.010)\end{array}$ & $\begin{array}{c}.015 \\
(.006)\end{array}$ \\
\hline Geographic proximity $\ldots \ldots \ldots \ldots \ldots \ldots$ & $\begin{array}{c}.006 \\
(.278)\end{array}$ & $\begin{array}{c}.017 \\
(.015)\end{array}$ & $\begin{array}{c}.017 \\
(.030)\end{array}$ \\
\hline Policy-planning board tie $\ldots \ldots \ldots \ldots \ldots$ & $\begin{array}{c}.022 \\
(.276)\end{array}$ & $\begin{array}{c}.072 \\
(.007)\end{array}$ & $\begin{array}{c}.069 \\
(.020)\end{array}$ \\
\hline Direct corporate board tie $\ldots \ldots \ldots \ldots$. & $\begin{array}{c}.143 \\
(.000)\end{array}$ & $\begin{array}{l}.125 \\
(.000)\end{array}$ & $\begin{array}{l}.150 \\
(.000)\end{array}$ \\
\hline Indirect board tie $($ distance $=2) \ldots \ldots$ & $\begin{array}{c}.143 \\
(.000)\end{array}$ & $\begin{array}{l}.124 \\
(.000)\end{array}$ & $\begin{array}{c}.144 \\
(.000)\end{array}$ \\
\hline Indirect board tie (distance $=3) \ldots \ldots$ & $\begin{array}{c}.118 \\
(.000)\end{array}$ & $\begin{array}{c}.096 \\
(.000)\end{array}$ & $\begin{array}{c}.107 \\
(.000)\end{array}$ \\
\hline Indirect board tie (distance $=4) \ldots \ldots$ & $\begin{array}{c}.111 \\
(.000)\end{array}$ & $\begin{array}{c}.067 \\
(.000)\end{array}$ & $\begin{array}{c}.074 \\
(.000)\end{array}$ \\
\hline Indirect board tie (distance $=5) \ldots$ & $\begin{array}{l}.100 \\
(.000)\end{array}$ & $\begin{array}{l}.041 \\
(.000)\end{array}$ & $\begin{array}{c}.052 \\
(.000)\end{array}$ \\
\hline Indirect board tie (distance $=6$ ) & $\begin{array}{c}.048 \\
(.005)\end{array}$ & $\begin{array}{c}.036 \\
(.004)\end{array}$ & $\begin{array}{c}.053 \\
(.000)\end{array}$ \\
\hline Intercept $\ldots \ldots \ldots \ldots \ldots \ldots \ldots \ldots \ldots \ldots \ldots \ldots$ & .614 & .263 & .147 \\
\hline$R^{2}$ & .024 & .011 & .011 \\
\hline
\end{tabular}

Note.-QAP probabilities in parentheses. $N=289,180$ dyads among 761 corporate directors.

or two links, the mean likelihood that a presidential candidate supported by one director will also be supported by the other is approximately 0.39 . Randomly selecting pairs of directors whose most direct connection is through ties of three or four links, the mean likelihood of common presidential contributions would be 0.34 . At a distance of five or six links it would be 0.31 , and at greater than six links it would be 0.26 . Hence, whether measured by party support or by contributions to presidential candidates, the propensity toward political cohesion is not distributed randomly across the network, but varies systematically by the degree of proximity among directors along the extended chains of direct and indirect ties that constitute the network.

This pattern is thrown into sharper relief if we trace the chains of directorship ties that emanate from what one can plausibly assume to be centers of economic and political influence within the business community. 
Numerous researchers have identified large commercial banks as uniquely powerful institutions within the U.S. economy and the boards of these banks as providing important arenas for mediating the potentially conflicting interests of different economic sectors and forging a common strategy for corporate capital (Zeitlin 1974, 1976; Useem 1984; Mintz and Schwartz 1985; Bearden and Mintz 1987; Soref and Zeitlin 1987; Burris 1992). The largest U.S. commercial bank in 1980 was Citicorp, and its chairman, Walter B. Wriston, was an early supporter of John Connally for president. As co-chairman of the Business Roundtable and chairmanelect of the Business Council, Wriston was a person of considerable influence within the business world, but the same could also be said of many of the other members of the Citicorp board. These included the chairmen or CEOs of eight Fortune 500 firms (Exxon, United Technologies, Xerox, Monsanto, W. R. Grace, Continental Group, Corning Glass, and Paccar) plus the oil field services and construction giant, Halliburton, and the country's largest privately owned textile firm, Milliken and Company. Wriston had worked with Connally on President Nixon's Productivity Commission when Connally was secretary of treasury. Connally had also served as a director of Halliburton and presumably had ties to some of the other Citicorp directors. Whatever the reason, Connally was the consensus candidate of the Citicorp board. Both Wriston and Citicorp president, William Spencer, contributed to Connally's campaign for a total of $\$ 4,000$. Of the 10 outside directors from the companies listed above, eight contributed to Connally for a total of $\$ 16,000 .{ }^{29}$ These Citicorp directors sat on other corporate boards, where they established links with 62 other top executives. These indirectly tied directors also leaned toward Connally, but not quite so strongly. Thirty-seven $(64 \%)$ contributed to Connally for a total of $\$ 40,200$. These directors, in turn, were tied to another 161 top executives on yet other boards. Ninety of these (56\%) contributed to Connally for a total of $\$ 78,070$. These, in turn, were tied to another 130 top executives, 48 of whom (37\%) contributed to Connally for a total of $\$ 46,050$. At this point-four links removed from the top management of Citicorp-support for Connally was only slightly above the average $(34 \%)$ of the remaining sample. Similar patterns of radiating influence can be traced from the boards of other major banks, although most do not exhibit quite the level of consensus reflected on the Citicorp board, nor was Connally always their top choice.

\footnotetext{
${ }^{29}$ Five members of the Citicorp board also contributed to Reagan ( $\$ 5,750$ total), and five contributed to Bush ( $\$ 4,250$ total). However, most of these contributions were made later in the primary campaign after Connally had withdrawn from the race.
} 


\section{DISCUSSION}

The chief finding of this study is the significant association that it reveals between corporate directorship ties and similarity of political behavior among corporate elites. This bolsters and extends Mizruchi's (1992) conclusions regarding the role of interlocking directorates in facilitating political cohesion within the business community. Not only are firms that are linked through common directors more likely to engage in cohesive political action, but the directors who create those interlocks among firms are also, as individuals, likely to exhibit similarities of political behavior. The microlevel mechanisms that might produce such political similarities are not difficult to imagine. Presumably, they include processes of information exchange, persuasion, deference, and conformity with group norms of the sort that have been extensively studied in the structurally oriented literature on political behavior and opinion formation (see Knoke [1990] for a review). ${ }^{30}$ Such an interpretation is consistent with the findings of interview studies with corporate multiple directors, who speak of their directorship ties to high-ranking executives of other firms as valuable sources of information and guidance on political as well as economic matters (Useem 1984, pp. 55-58).

At the same time, comparing the findings of this study with those of Mizruchi (1992) points toward differences in the processes that produce political cohesion among corporations and those that facilitate cohesion among individual corporate elites-at least insofar as campaign contributions are concerned. The main difference is that, for individual directors, both direct and indirect ties are significantly associated with similarity of political contributions. For the corporations in Mizruchi's study, only one specific type of indirect interlock is significantly associated with similarity of political contributions; direct interlocks between firms are not. This means that immediate proximity within networks of interlocking

\footnotetext{
${ }^{30}$ Similar mechanisms are invoked to explain the impact of directorship ties on the interorganizational diffusion of managerial practices (Davis 1991; Haunschild 1993; Palmer, Jennings, and Zhou 1993; Davis and Greve 1997). An alternative interpretation, of course, is that the association between directorship ties and similarity of political behavior indicates that corporate directors are selected on the basis of political affinity. There are several reasons why this is unlikely to explain the patterns revealed in this study. First, the membership of corporate boards tends to be relatively stable over an extended number of years, whereas candidates and issues vary from one election to the next. Thus, in the vast majority of cases, the creation of directorship ties among corporate elites preceded their decisions about which candidates to support in 1980 by a substantial period of time. Second, much of the variation in political behavior measured in this study, especially on the two presidential contribution variables, concerns relatively nuanced choices among broadly similar candidates (e.g., the choice to support John Connally over Ronald Reagan or vice versa) rather than sharp ideological differences of the sort that might plausibly lessen one's chances for board nomination.
} 
directorates is more conducive to similarity of political behavior among individual corporate elites than it is among corporations.

We cannot rule out the possibility that these divergent findings are partly the result of differences in sampling and measurement, although this appears unlikely. Mizruchi's sample is restricted to industrial firms, whereas this study includes large firms from all branches of the economy. However, a replication of this study using a reduced sample of 374 corporate elites whose primary executive position is with industrial firms also reveals strong effects of both direct and indirect ties on all three measures of political cohesion. Mizruchi also controls for the effects of several industry-level variables (e.g., measures of market constraint based on industry-level concentration ratios and input-output tables) that are meaningful or available only for industrial firms and, therefore, not used in this study. However, the effects of these variables in Mizruchi's study are generally modest, and a reanalysis of Mizrichi's data that omits these controls does not alter his findings with respect to the director interlock variables. Finally, this study gives greater attention to contributions to candidates for president, because this is the only race that attracts sufficient contributions by individual corporate elites to allow for detailed measures of support for identical or competing candidates. Mizruchi necessarily gives greater attention to congressional races, since these receive the bulk of corporate PAC contributions. However, both Mizruchi and I employ an identical measure of the share of contributions going to each of the two major parties, and the results on this dependent variable are no less divergent than on the candidate-specific measures.

Moreover, there are sound reasons for believing that direct, person-toperson ties between corporate elites should have greater salience for their individual decisions regarding political contributions than direct interlocks among firms are likely to have for the political spending of corporations. Individuals and firms are different types of social actors. Individuals are arguably more profoundly influenced by other people, whereas firms tend to have less permeable barriers to their environment. This, indeed, is how they preserve the goals and internal arrangements of the organization. Individuals have the discretion to choose which candidates or parties they will support without having to seek the formal approval of others. In the case of firms, the sharing of a director between corporations merely creates a channel of information or influence that is then filtered through the larger bureaucratic process by which campaign contributions are decided. Important in this regard is the fact that corporate decisions about campaign spending are typically constrained by pragmatic considerations related to their role as an adjunct to corporate lobbying (Handler and Mulkern 1982; Sabato 1984; Clawson, Neustadtl, and Weller 1998). Individual contributors are less constrained by such 
pragmatic concerns and freer to follow their personal preferences in deciding which candidates or parties to support. Finally, a substantial part of campaign fundraising targeted at individual large donors is organized by well-connected political entrepreneurs who skillfully exploit networks of social and business ties among corporate elites as avenues for soliciting campaign contributions (Brown et al. 1995). Direct solicitation of political contributions among interconnected firms is not uncommon (Clawson et al. 1998), but it is not the usual way in which corporate decisions regarding campaign contributions are initiated.

While direct ties among corporate board members are significantly associated with similarities of political behavior, it is also evident from this study that indirect ties-that is, ties that do not entail a person-to-person connection but are established through one or more intermediaries-also contribute to political cohesion. Generally speaking, the closer the proximity of dyads of directors within the network of interlocking directorates, the greater their similarity of political behavior. Proximity is therefore important. However, even at a distance of four or five links, indirect ties remain significantly associated with similarity of political behavior. Hence, much of the political importance of interlocking directorships is likely to be missed if we remain narrowly focused on direct interlocks.

These findings point to the need to move beyond the level of individual dyads toward a more structural understanding of interlocking directorates. From the standpoint of the individual dyads that make up the interlock network, indirect ties represent situations in which one director gives and receives influence vis-à-vis another director (through the exchange of information, persuasion, deference, etc.), who, in turn, gives and receives influence with another director, who gives and receives influence with another director, and so forth down the line. Directors who are closely tied to one another give and receive the full weight of such influence, while those who are several intermediaries removed presumably receive a weaker dose relative to other influences that are impinging upon them. At some point, however, we are forced to recognize that all of these extended chains of communication and influence are cross-cutting and overlapping, so that what we are actually witnessing is more like a multidimensional field of force in which individual directors are positioned or "embedded" (Granovetter 1985) within the network at varying distances to one another and, thus, simultaneously subject to reinforcing (and/or competing) influences of varying magnitudes. This notion is nicely captured by Useem (1984, p. 56) who describes the interlocking directorate as a "transcendent network" in which each localized tie assimilates and transmits the influence of innumerable other ties, both proximate and remote. On this point, our findings converge with the more general conclusions of Mizruchi's (1992) study of interfirm interlocks. As with cor- 
porate actors, the political behavior of individual directors is influenced not only by those other directors with whom they share a direct tie, but also by their location within the larger structure of multiple and overlapping ties that comprise the interlock network.

Judging from the findings of previous research, it can also be argued that the network of directorship ties is, itself, embedded within other networks of formal and informal ties among corporate elites. The decision to invite an executive of one firm to join the board of another typically presupposes some prior contact or association through which the board candidate became recognized as a person worthy of trust and able to provide useful advice and information. Previous research suggests that informal social interaction within exclusive metropolitan upper-class clubs plays an important role in the selection of outside corporate directors (Johnsen and Mintz 1989; Kono et al. 1998; Useem 1984; Bonacich and Domhoff 1981; Soref 1976, 1980; Soref and Zeitlin 1987). Interpersonal ties created through membership on noncorporate boards of directors, kinship relations, or attendance at elite boarding schools and universities may also be important (Domhoff 1970, 1974; Useem 1984). The network of corporate directorship ties can thus be viewed as one thread in the larger fabric of social ties connecting corporate elites. It is therefore possible that the politically cohesive effects of interlocking corporate directorships are both reinforced and complemented by the other social networks with which they are intertwined. More systematic empirical research on the political consequences of these associated networks would be valuable for assessing the arguments advanced by elite and class cohesion theories of corporate power.

One of the unexpected results of this study is the fact that neither common industry nor geographic proximity has pronounced effects on similarity of party support among individual corporate elites. As noted earlier, geographic proximity has been shown to promote similarity of party support among firms (Mizruchi 1992). I can only speculate as to why geographic proximity should have more pronounced effects on similarity of party support among corporations than among individual corporate elites. It is possible that other ways of measuring geographic proximity might yield different results, although a number of alternative measures were examined without yielding any change in these findings. ${ }^{31}$

\footnotetext{
${ }^{31}$ Measures of geographic proximity constructed at the metropolitan level show weaker effects on similarity of political behavior than the measure used here, which (like the one used by Mizruchi) is constructed at the state level. Some measures of geographic proximity constructed at the level of multistate regions yield slightly stronger effects on similarity of party contributions, but these effects still fall below the threshold of significance. Moreover, measures of geographic proximity based on regions rather than states have dramatically weaker effects on similarity of presidential contributions.
} 
The most plausible explanation for this difference is one suggested by Mizruchi (1992, p. 140), which is simply that firms, because of the benefits they derive from maintaining cordial relations with potentially sympathetic members of Congress, are likely to contribute disproportionately to congressional incumbents in their own state or region. Incumbents are virtually certain of reelection in most congressional races, and, regardless of party or ideology, members of Congress can be expected to demonstrate special sensitivity to the concerns of their regional constituents. Because Democratic incumbents tend to be concentrated in some regions and Republican incumbents in others, corporate PAC contributions will tend to mirror, at least in part, these regional differences in party strength. Of course, individual corporate elites also contribute to congressional incumbents from their own region for many of the same reasons that firms do. But buying access with incumbents is a much lower priority for individual contributors compared with seeking to influence the outcome of the election. Consequently, individual corporate elites donate a much larger share of their money to national party committees, presidential campaigns, and high-profile or closely contested Senate races, regardless of where they occur. Partisan preferences of individual corporate elites are therefore less likely to converge toward some regional norm purely as a result of their pragmatic interest in staying on good terms with local incumbents. ${ }^{32}$

\section{CONCLUSION}

This study provides evidence for the thesis that interlocking directorates increase the potential for political cohesion among corporate elites. Although this is by no means a novel thesis within the corporate power structure literature, it is one that has frequently been disputed and whose

\footnotetext{
${ }^{32}$ It is also instructive to compare the results of this study with the findings of Burris (2001). Using individuals rather than dyads as the unit of analysis, the earlier study found that geographic region was a significant predictor of party support among corporate elites. From this, one might infer that geographic proximity should be associated with similarity of party support. Upon reflection, however, it should be evident that these two are not equivalent. If the norm for corporate elites is to favor Republicans, but a disproproportionate number of corporate elites in certain states support Democrats to a degree that exceeds the norm, then dummy variables for residence in those states will be associated with party preference. At the same time, dyads of corporate elites from those same states will tend to be less politically cohesive than average because a larger number of them deviate from the Republican norm. Dyads of corporate elites from other states where conformity with the Republican norm is accentuated will tend to be more politically cohesive than average. Hence, there may be no consistent association between geographic proximity and similarity of party support. This illustrates the pitfalls of attempting to infer sources of political cohesion from research that is not based explicitly on dyadic data.
} 
credibility has been defended, heretofore, mainly in terms of its surface plausibility rather than through empirical demonstration. The fact that corporate elites who are linked through common board memberships show evidence of similar political behavior will not come as a surprise to most defenders of elite or class cohesion theories of corporate power. More impressive is the fact that the effects of such directorship ties on political cohesion are stronger by several magnitudes than the effects of shared characteristics, like common industry or geographic proximity, that adherents of virtually all competing theoretical perspectives agree are conducive to political cohesion. Indeed, pairs of top officers of the same firm are only moderately more likely to engage in similar political behavior than two officers of different firms who are tied through interlocking directorships. The evidence presented in this study should therefore be convincing even to those scholars who traditionally have been most skeptical of the political importance of interlocking directorates. When we consider that, on average, the top officers of large corporations are linked to roughly a third of all other top officers of large corporations through chains of interlocking directorships of no more than four or five links, and that linkages of this distance are significantly associated with similarity of political behavior, then the thesis that interlocking directorships enhance the potential for political cohesion across the entire big business community becomes more persuasive. Remember also that this includes only links that are created through corporate boards, ignoring the numerous ties created through noncorporate boards, not to mention social ties of various kinds.

This study also lends support to the thesis that political action by individual corporate elites follows a different logic from political action by corporations. ${ }^{33}$ In numerous areas — of which the study of interlocking directorates is a particularly good example-we know much more about the social organization and political behavior of firms than we do about individual members of the corporate elite. Correspondingly, there has been a temptation to speak of the "politics of business," as if this were reducible to the politics of corporations. Mintz (2002) calls attention to this in her recent review of the literature and emphasizes the importance of distinguishing between elite unity and intercorporate unity. As this study shows, there are similarities in the conditions and mechanisms that facilitate

\footnotetext{
${ }^{33}$ See Burris (2001) for an elaboration of this thesis and supporting evidence from a study that compares political contributions made by corporations with those of corporate elites. Among the limitations of this earlier study was its inability to address one of the chief concerns of the literature-namely, the issue of business unity. The present study, by conceptualizing and measuring political cohesion at the dyadic level, is able to address this issue directly and to show that the conditions that facilitate or inhibit business unity also operate differently at the individual and the firm level.
} 
political unity among corporations and among corporate elites, but there are also important differences. With respect to campaign contributions, firms tend to be more constrained by pragmatic concerns, whereas individual corporate elites are freer to follow their partisan sympathies or personal preferences. This encourages certain forms of political unity among corporations (such as the propensity to coalesce in support of congressional incumbents from their region) that are not as evident among individual corporate elites. Conversely, other forms of political cohesion (such as the propensity to align politically with those to whom one is directly tied within the interlock network) are more evident among individual corporate elites than among firms. Such findings should serve as a caution against the temptation to conflate these two forms of political action. Both types of political action impact the system in important ways, and evidence on both is necessary for a balanced account of the manner in which political influence is mobilized within the business community.

With respect to its broader implications, this study adds to an accumulating body of empirical support for the general proposition that political action should be studied in terms of its embeddedness within social networks (Knoke 1990). The more common view-exemplified by pluralist interest-group theory, but also common to a variety of other theoretical perspectives-locates the sources of political action in individually calculated interests and the potential for political unity (or disunity) in the coincidence (or conflict) of such interests. This view is typically associated with a methodology that takes attributes attached to individual actors, rather than concrete and ongoing social relations among actors, as the focus of analysis. As this study shows, social ties among actors have significant consequences for political action that go beyond anything that can be explained in terms of attributes measured at the level of the individual actor. The study thus speaks to the merits of a structural perspective on political behavior and the importance of gathering and analyzing data not just on individual actors, but on the network of social ties among those actors.

\section{REFERENCES}

Allen, Michael Patrick. 1974. "The Structure of Interorganizational Elite Cooptation: Interlocking Corporate Directorates." American Sociological Review 39:393-406.

_ 1978. "Economic Interest Groups and the Corporate Elite Structure." Social Science Quarterly 58:597-615.

Allen, Michael Patrick, and Philip Broyles. 1989. "Class Hegemony and Political Finance." American Sociological Review 54:275-87.

Bearden, James, and Beth Mintz. 1985. "Regionality and Integration in the United States Interlock Network." Pp. 234-49 in Networks of Corporate Power, edited by Frans Stokman, Rolf Ziegler, and John Scott. New York: Blackwell.

_ 1987. "The Structure of Class Cohesion: The Corporate Network and Its Dual." 
Pp. 187-207 in Intercorporate Relations: The Structural Analysis of Business, edited by Mark S. Mizruchi and Michael Schwartz. New York: Cambridge University Press.

Berk, Richard A. 1983. "An Introduction to Sample Selection Bias in Sociological Data." American Sociological Review 48:386-98.

Berk, Richard A., and Subhash C. Ray. 1982. "Selection Biases in Sociological Data." Social Science Research 11:352-98.

Berle, Adolph A. 1963. The American Economic Republic. New York: Harcourt, Brace, \& World.

Bonacich, Phillip, and G. William Domhoff. 1981. "Latent Classes and Group Memberships." Social Networks 3:175-96.

Borgatti, Stephen P., Martin G. Everett, and Linton C. Freeman. 1999. UCINET 5 for Windows: Software for Social Network Analysis. Natick, Mass.: Analytic Technologies.

Breen, Richard. 1996. Regression Models: Censored, Sample Selected, or Truncated Data. Thousand Oaks, Calif.: Sage.

Breiger, Ronald L. 1974. "The Duality of Persons and Groups." Social Forces 53: 181-90.

Brown, Clifford W., Lynda W. Powell, and Clyde Wilcox. 1995. Serious Money. New York: Cambridge University Press.

Broyles, Philip A. 1993. "The Corporate Elite Goes to Washington: Presidential Campaign Contributions of Corporate Officers." Social Science Research 22:72-91.

Burch, Philip H., Jr. 1983. "The American Establishment: Its Historical Development and Major Economic Components." Pp. 83-156 in Research in Political Economy, vol. 6. Edited by Paul Zarembka. Greenwich, Conn.: JAI Press.

Burris, Val. 1991. "Director Interlocks and the Political Behavior of Corporations and Corporate Elites." Social Science Quarterly 72:537-51.

_. 1992. "Elite Policy-Planning Networks in the United States." Pp. 111-34 in Research in Politics and Society, vol. 4: The Political Consequences of Social Networks, edited by Gwen Moore and J. Allen Whitt. Greenwich, Conn.: JAI Press. . 2001. "The Two Faces of Capital: Corporations and Individual Capitalists as Political Actors." American Sociological Review 66:361-81.

Clawson, Dan, Alan Neustadtl, and Mark Weller. 1998. Dollars and Votes. Philadelphia: Temple University Press.

Dahl, Robert. 1961. Who Governs? New Haven, Conn.: Yale University Press.

Davis, Gerald F. 1991. "Agents without Principles? The Spread of the Poison Pill through the Intercorporate Network." Administrative Science Quarterly 36:583-613.

Davis, Gerald F., and Henrich R. Greve. 1997. "Corporate Elite Networks and Governance Changes in the 1980s." American Journal of Sociology 103:1-37.

Davis, Mike. 1981. "The New Right's Road to Power." New Left Review 128:28-49.

Domhoff, G. William. 1967. Who Rules America? Englewood Cliffs, N.J.: PrenticeHall.

- 1970. The Higher Circles. New York: Vintage Books.

—. 1972. Fat Cats and Democrats. Englewood Cliffs, N.J.: Prentice-Hall.

—. 1974. The Bohemian Grove and Other Retreats. New York: Harper \& Row. 1987. "The Wagner Act and Theories of the State." Political Power and Social Theory 6:159-85.

Dye, Thomas R. 1976. Who's Running America? Englewood Cliffs, N.J.: Prentice-Hall. 2001. Top Down Policymaking. New York: Chatham House.

Epstein, Edwin M. 1969. The Corporation in American Politics. Englewood Cliffs, N.J.: Prentice-Hall.

Federal Election Commission. 2001. FEC Reports on Congressional Financial Activity for 2000. Washington, D.C.: Federal Election Commission.

Ferguson, Thomas. 1995. Golden Rule. Chicago: University of Chicago Press. 
Ferguson, Thomas, and Joel Rogers. 1986. Right Turn. New York: Hill \& Wang.

Granovetter, Mark. 1985. "Economic Action and Social Structure: The Problem of Embeddedness." American Journal of Sociology 91:481-510.

Green, John, Paul Herrnson, Lynda Powell, and Clyde Wilcox. 1998. "Individual Congressional Campaign Contributors." Manuscript. Akron, Ohio: University of Akron.

Greene, William H. 2000. Econometric Analysis, 4th ed. Upper Saddle River, N.J.: Prentice-Hall.

Handler, Edward, and John Mulkern. 1982. Business in Politics. Lexington, Mass.: Lexington Books.

Hartman, Raymond. 1991. "A Monte Carlo Analysis of Alternative Estimators in Models Involving Selectivity.” Journal of Business and Economic Statistics 9:41-49.

Haunschild, Pamela R. 1993. "Interorganizational Imitation: The Impact of Interlocks on Corporate Acquisition Activity." Administrative Science Quarterly 38:564-92.

Heard, Alexander. 1960. The Costs of Democracy. Chapel Hill: University of North Carolina Press.

Heckman, James J. 1979. "Sample Selection Bias as a Specification Error." Econometrica 47:153-61.

Johnsen, Eugene, and Beth Mintz. 1989. "Organizational versus Class Components of Director Networks." Pp. 57-80 in Networks of Power, edited by Robert Perrucci and Harry R. Potter. New York: Aldine de Gruyter.

Knoke, David. 1990. Political Networks: The Structural Perspective. New York: Cambridge University Press.

Koenig, Thomas, Robert Gogel, and John Sonquist. 1979. "Models of the Significance of Interlocking Corporate Directorates." American Journal of Economics and Sociology 38:173-86.

Koenig, Thomas, and John Sonquist. 1977. "Interlocking Directorates in the Top U.S. Firms." Insurgent Sociologist 5:196-229.

Kono, Clifford, Donald Palmer, Roger Friedland, and Matthew Zafonte. 1998. "Lost in Space: The Geography of Corporate Interlocking Directorates." American Journal of Sociology 103:863-911.

Krackhardt, David. 1987. "QAP Partialling as a Test of Spuriousness.” Social Networks 9:171-86.

_. 1988. "Predicting with Networks: Nonparametric Multiple Regression Analysis of Dyadic Data." Social Networks 10:359-81.

Mariolis, Peter. 1975. "Interlocking Directorates and Control of Corporations." Social Science Quarterly 56:425-39.

Marquis. 1979-80. Who's Who in Finance and Industry. Chicago: Marquis Who's Who, Inc.

Mills, C. Wright. 1956. The Power Elite. New York: Oxford University Press.

Mintz, Beth. 2002. "Elites and Politics: The Corporate Elite and the Capitalist Class in the United States." Pp. 53-77 in Research in Political Sociology, vol. 11. Edited by Betty A. Dobratz, Timothy Buzzell, and Lisa K. Waldner. Stamford, Conn.: JAI Press.

Mintz, Beth, and Michael Schwartz. 1985. The Power Structure of American Business. Chicago: University of Chicago Press.

Mizruchi, Mark S. 1982. The American Corporate Network, 1904-1974. Beverly Hills, Calif.: Sage.

1992. The Structure of Corporate Political Action. Cambridge, Mass.: Harvard University Press.

- 1996. "What Do Interlocks Do? An Analysis, Critique, and Assessment of Research on Interlocking Directorates." Annual Review of Sociology 22:271-98.

Mizruchi, Mark S., and Thomas Koenig. 1986. "Economic Sources of Corporate Political Consensus." American Sociological Review 51:482-91. 
Moody's Investors Service. 1980. Moody's Manuals. New York: Moody's Investors Service.

Nelson, Forrest. 1984. "Efficiency of the Two-Step Estimator for Models with Endogenous Sample Selection." Journal of Econometrics 24:181-96.

Ornstein, Michael. 1980. "Interlocking Directorates in Canada: Evidence from Replacement Patterns." Social Networks 4:3-25.

Overacker, Louise. 1933. "Campaign Funds in a Depression Year." American Political Science Review 27:769-83.

- 1937. "Campaign Funds in the Presidential Election of 1936." American Political Science Review 31:473-98.

- 1941. "Campaign Finance in the Presidential Election of 1940." American Political Science Review 35:701-27.

—. 1945. "Presidential Campaign Funds, 1944." American Political Science Review 39:899-925.

Palmer, Donald. 1983. "Broken Ties: Interlocking Directorates and Intercorporate Coordination." Administrative Science Quarterly 28:40-55.

Palmer, Donald, and Brad M. Barber. 2001. "Challengers, Elites, and Owning Families: A Social Class Theory of Corporate Acquisitions in the 1960s." Administrative Science Quarterly 46:87-120.

Palmer, Donald, and Roger Friedland. 1987. "Corporation, Class, and City System." Pp. 145-84 in Intercorporate Relations: The Structural Analysis of Business, edited by Mark S. Mizruchi and Michael Schwartz. New York: Cambridge University Press.

Palmer, Donald, Roger Friedland, and Jitendra Singh. 1986. "The Ties that Bind: Organizational and Class Bases of Stability in a Corporate Interlock Network." American Sociological Review 51:781-96.

Palmer, Donald, P. Devereaux Jennings, and Xueguang Zhou. 1993. "Late Adoption of the Multidivisional Form by Large U.S. Corporations." Administrative Science Quarterly 38:100-131.

Peschek, Joseph G. 1987. Policy-Planning Organizations. Philadelphia: Temple University Press.

Rose, Arnold M. 1967. The Power Structure. New York: Oxford University Press.

Sabato, Larry J. 1984. PAC Power. New York: Norton.

Sale, Kirkpatrick. 1975. Power Shift. New York: Random House.

Smith, James Allen. 1991. The Idea Brokers. New York: Free Press.

Smith, Mark A. 2000. American Business and Political Power. Chicago: University of Chicago Press.

Soref, Michael. 1976. "Social Class and a Division of Labor within the Corporate Elite." Sociological Quarterly 17:360-68.

- 1980. "The Finance Capitalists." Pp. 62-82 in Classes, Class Conflict, and the State, edited by Maurice Zeitlin. Cambridge, Mass.: Winthrop.

Soref, Michael, and Maurice Zeitlin. 1987. "Finance Capital and the Internal Structure of the Capitalist Class in the United States." Pp. 56-84 in Intercorporate Relations: The Structural Analysis of Business, edited by Mark S. Mizruchi and Michael Schwartz. New York: Cambridge University Press.

Standard \& Poor's. 1980. Register of Corporations, Directors and Executives. New York: Standard \& Poor's.

Stearns, Linda Brewster, and Mark S. Mizruchi. 1986. "Broken-Tie Reconstitution and the Functions of Interorganizational Interlocks: A Reexamination." Administrative Science Quarterly 31:522-38.

Stolzenberg, Ross M., and Daniel A. Relles. 1990. "Theory Testing in a World of Constrained Research Design." Sociological Methods and Research 18:395-415.

—. 1997. "Tools for Intuition about Sample Selection Bias and Its Correction." American Sociological Review 62:494-507. 


\section{Interlocking Corporate Directorates}

Truman, David. 1951. The Governmental Process. New York: Knopf.

Useem, Michael. 1984. The Inner Circle. New York: Oxford University Press.

Vogel, David. 1989. Fluctuating Fortunes: The Political Power of American Business. New York: Basic Books.

Ward Publications. 1981. Ward's Directory of 55,000 Largest U.S. Corporations. Petaluma, Calif.: B. H. Ward Publications.

Watts, Duncan J. 1999. Small Worlds: The Dynamics of Networks between Order and Randomness. Princeton, N.J.: Princeton University Press.

Webber, Michael J. 2000. New Deal Fat Cats. New York: Fordham University Press.

Winship, Christopher, and Robert D. Mare. 1992. "Models for Sample Selection Bias." Annual Review of Sociology 18:327-50.

Zeitlin, Maurice. 1974. "Corporate Ownership and Control: The Large Corporation and the Capitalist Class." American Journal of Sociology 79:1073-1119.

- 1976. "On Class Theory of the Large Corporation: Response to Allen." American Journal of Sociology 81:894-904.

Zeitlin, Maurice, W. Lawrence Neuman, and Richard E. Ratcliff. 1976. "Class Segments: Agrarian Property and Political Leadership in the Capitalist Class of Chile." American Sociological Review 41:1006-29. 